\title{
Investigation of Copper Removal from Aqueous Solution by Cement Kiln Dust as Industrial By-Product
}

\author{
Ahmed A. El-Refaey ${ }^{1}$
}

\begin{abstract}
This study investigated the copper $\left(\mathrm{Cu}^{+2}\right)$ removal from aqueous solution by cement kiln dust (CKD) as industrial by-product in cement manufacturing process. CKD was identified by Fourier transform infrared (FTIR), scanning electron microscopy (SEM) and surface areas show the differences of physicochemical properties. Batch equilibrium experiments were carried out at 20,25 and 30 ${ }^{\circ} \mathrm{C}$ with time intervals extended to $96 \mathrm{~h}$ to investigate the efficiency of the CKD in the removal of $\mathrm{Cu}^{+2}$. CKD expressed high affinity for removal of $\mathrm{Cu}^{+2}$ and was not affected by temperature or time. The removal of $\mathrm{Cu}^{+2}$ was indicated by changes of FTIR and SEM images before and after sorption experiments. The kinetic data were evaluated by fractional power, Elovich, pseudo-first order and pseudo-second-order kinetic models. The kinetic studies demonstrated that rate of the removal followed pseudo-second-order kinetic model $\left(r^{2}=0.99\right)$. Thermodynamic parameters, the change of free energy $\left(\Delta G^{\circ}\right)$, enthalpy $\left(\Delta H^{\circ}\right)$ and entropy $\left(\Delta S^{\circ}\right)$ were calculated for predicting the nature of adsorption. The parameters showed that the process was feasible, spontaneous and exothermic under experiment conditions. Solubility equilibrium for various expected copper compounds was estimated and the solubility of copper in $\mathrm{Cu}-\mathrm{CKD}$ system suggested to be controlled by $\mathrm{Cu} \mathrm{CO}_{3}$ precipitation under experiment condition. The results indicated that $\mathrm{CKD}$ can be used as a low cost and effective sorbent for copper ions from aqueous solutions.
\end{abstract}

Key words: Copper, Cement Kiln Dust (CKD), Sorption Kinetics, Thermodynamic, Solubility Equilibrium

\section{INTRODUCTION}

Heavy metal pollution became critical serious environmental problems and public health issue. Heavy metals treatment is of special concern because of their recalcitrance, non degradable and persistence in the environment (Shareef, 2009 and Fenglian and Wang, 2011). Copper is a crucial micro-nutrients for most, if not all, living organisms and main component of numerous enzymes that are responsible for the oxidation-reduction reactions and has many commercial uses such as make electrical wiring, pipes, valves, coins, cooking utensils, building materials and in electroplating. Also, Copper is used through fertilizer, fungicides, algicides, insecticides, dyes manufacture and petroleum refining. Excess exposure and accumulation in living organisms can cause serious disturbances such

${ }^{1}$ Department of Soil \& Water Science, Faculty of Desert and

Environmental Agriculture, Alexandria University (Matrouh branch).

Egypt; E-Mails: ahmedelrefaey@alexu.edu.eg

Received March 9, 2017, Accepted March 30, 2017 as headache, nausea, vomiting, diarrhea, cramps, convulsions, liver injury and acute poisoning to the human body or even death (Karabulut et al. 2000; Sobecka, 2001; WHO, 2004; Chen, 2005 and Paulino et al., 2006).

Generally, various technologies for elimination of heavy metal from wastewater have been used. These methods include chemical oxidation, reduction, chemical precipitation, solvent extraction, ion-exchange, adsorption, membrane filtration, coagulationflocculation, flotation and electrochemical methods (Suzuki 1997; Ochie et al. 2008; Barakat, 2011; Fenglian and Wang, 2011). Among these methods, the adsorption can be an effective method in heavy metals treatment (Huang and Morehart, 1990; Bayat, 2002; Suzuki et al., 2005; Ahmad et al. 2010; Bilal et al. 2013). Huge economic sorbents can be used as materials which are abundant in nature or can be originated as a waste or byproduct from industry. Managing industrial by-product and wastes is a must to insure a clean and safe environment (Ibrahim et al., 2009).

Cement kiln dust (CKD) is a fine-grained solid material created as a by-product material in the kiln in the cement manufacturing process. Moreover CKD can be effectively used in removal heavy metals ions from solutions by adsorption as a low-cost and effective sorbent because of its high contents of alkali oxides, high surface area and excellent thermal resistance (Pigaga et al., 2005; Zaki et al. 2007; Rahman et al. 2011; Mackie and Walsh, 2012; Salem and Velayi, 2012; El-Refaey,2016).

Therefore, the aim of this research is to investigate and evaluate the removal of copper $\left(\mathrm{Cu}^{+2}\right)$ from hazard aqueous solution by cement kiln dust as an industrial byproduct. To achieve this aim, adsorption experiments were carried out at different temperatures with time interval extended to $96 \mathrm{~h}$. Furthermore, the kinetic data were evaluated to fractional power, elovich, pseudofirst-order and pseudo second-order models to explain the reaction process and understand the sorption mechanism. Also, the thermodynamic parameters describing the nature of $\mathrm{Cu}^{2+}$ sorption onto $\mathrm{CKD}$ were examined. Finally, solubility equilibrium for various 
expected copper compounds were evaluated using solubility diagrams.

\section{MATERIALS AND METHODS}

\section{Characterization of CKD}

CKD was obtained from El-Amerya of cement plants, Alexandria, Egypt. Some Characteristics of CKD is record in table (1). The $\mathrm{pH}$ was measured in distilled water $\left(1: 2.5 \mathrm{H}_{2} \mathrm{O}\right)$. The major components of CKD are calcium carbonate of $47.6 \%$; oxides of aluminum of $4.2 \%$; iron of $2.8 \%$ and magnesium of $2.3 \%$; free lime of $4.8 \%$ and some alkali salts such as sodium and potassium (Mahmoued, 2010, El-Refaey, 2016). Total carbon, nitrogen, hydrogen content and sulfur in CKD were determined by CHNS analyzer (Elementar, Vario EL, Germany) (Table.1).

The specific surface area of CKD was determined from $\mathrm{N}_{2}$ adsorption isotherms at $77 \mathrm{~K}$ using a gas sorption analyzer (Beckman Coulter SA(TM) 3100 Surface Area and Pore Size Analyzer). BrunauerEmmett-Teller (BET) adsorption isotherms equation was applied to calculate surface areas. The pore size distribution was determined by the Barrett-JoynerHalenda (BJH) method from the $\mathrm{N}_{2}$ desorption isotherms (Park and Komarneni, 1998; Nader, 2015).

The Fourier transform-infrared (FTIR) spectra were obtained at the range $400-4,000 \mathrm{~cm}^{-1}$ by a Fourier transforms infrared spectrometer (model FT/IR-5300, JASCO Corporation, Japan) using $\mathrm{KBr}$ pellet method. A small sample of powder CKD was amounted on a potassium bromide $(\mathrm{KBr})$ disc which had been earlier scanned as a background in the FTIR analysis. FTIR were measured before and after sorption experiments.

Scanning electron microscopy (SEM) was performed by using a Phillips SEM-505 scanning electron microscope and operated at $300 \mathrm{kV} / \mathrm{SE}$ and $50{ }^{\circ} \mathrm{C}$ inclination. Before examination, samples were coated with gold in a sputter-coating unit (Edwards Vacuum Components Ltd, Sussex, UK) for electrical conduction. CKD samples were dried overnight at approximately $105{ }^{\circ} \mathrm{C}$ under vacuum before SEM examination. SEM images were obtained at various magnification scales before and after sorption experiments.

\section{Sorption experiments and analytical methods}

Separate suspensions $(4 \mathrm{~g} / 0.8 \mathrm{~L}$ in $0.01 \mathrm{M} \mathrm{KCl})$ were shaking end-over-end at $300 \mathrm{rpm}$ for $24 \mathrm{~h}$ to reach equilibrium. At the initial time, $\mathrm{pH}$ measured then adding $\mathrm{Cu}$ (II) to each reactor as $\mathrm{Cu} \mathrm{Cl}_{2}$, for the final concentration of $1.5 \mathrm{mM}$ in each reactor. The adsorption isotherm was conducted at 20,25 and $30^{\circ} \mathrm{C}$ for intervals extended to $96 \mathrm{~h}$. Suspensions were filtered $(0.45 \mu \mathrm{m})$ immediately following the $\mathrm{pH}$ measurement. Metal ion concentrations were measured in Filtrate using Atomic Absorption Spectrophotometer Varian Spectra (model 220). All measurements, Metal concentrations and $\mathrm{pH}$ measurements were determined in duplicate.

The adsorption amount $\left(\mathrm{q}_{\mathrm{t}}\right)$ and the percentage of adsorption ( $\mathrm{S} \%$ ) is calculated according to:

$$
\begin{aligned}
& q_{t}=\frac{\left(c_{0}-c_{t}\right) \nu}{m} \\
& S \%=\frac{\left(c_{0}-c_{t}\right)}{c_{t}}
\end{aligned}
$$

Where $\mathrm{q}_{\mathrm{t}}$ is the metal ion adsorption amount at time $\mathrm{t}$ $(\mathrm{mg} / \mathrm{g}), \mathrm{S} \%$ is the adsorption percentage $(\%), \mathrm{m}$ is the weight of CKD sample (g), $\mathrm{V}$ is the solution volume $\left(\mathrm{dm}^{3}\right)$, and $\mathrm{c}_{0}$ and $\mathrm{c}_{\mathrm{t}}$ are the initial and equilibrium concentrations of $\mathrm{Cu}^{++}$ions in solution, respectively.

\section{Solubility equilibrium estimation}

Solubility measurements in $\mathrm{Cu}$ treated $\mathrm{CKD}$ aimed at predicting indirectly the solid phases controlling the copper concentration through calculating their ion activity products. Compounds of these solid phases to ionize and form complexes in solution. Davies equation was employed for estimating the single ion activity coefficient $\left(\gamma_{\mathrm{i}}\right)$ in solution for the ionic species (i).

$\log \gamma_{\mathrm{i}}=-\mathrm{A} Z_{\mathrm{i}}^{2}[(\sqrt{\mathrm{I}} / \sqrt{ } 1+\textrm{I})-0.3 \mathrm{I}]$

where $\mathrm{A}$ is equals 0.509 for water at $25^{\circ} \mathrm{C}$ and is a temperature dependant constant (Lindsay (1979), $Z_{\mathrm{i}}$ is the valence of the solute and I is the ionic strength $(<0.5$ $\mathrm{mol} / \mathrm{L}$ ) of the solution based on concentration expressed in $\mathrm{mol} / \mathrm{L}$ and can calculated from the flowing equation (Griffin and Jurinak, 1973):

$\mathrm{I}=0.013 \mathrm{EC} \quad \mathrm{r}^{2}=0.99$ (4)

Where EC is electrical conductivity expressed on $\mathrm{dS} / \mathrm{m}$ at $25^{\circ} \mathrm{C}$. With $\mathrm{r}^{2}$ of 0.99 indicates a very high correlation between calculated ionic strength (I) by the above empirical equation that based on Debye-Hückel equation $\left(I=1 / 2 \sum C_{i} Z_{i}^{2}\right)$ where $C_{i}$ is the concentration in $\mathrm{mol} / \mathrm{L}$ of ion (i). This empirical relationship is particularly useful when the complete composition of an aqueous solution is unknown or where ion pair formation in solution. The ions activities of interested cations $\left(\mathrm{Cu}^{2+}, \mathrm{Ca}^{2+}\right.$ and $\left.\mathrm{H}^{+}\right)$and anions $\left(\mathrm{Cl}^{-}, \mathrm{HCO}_{3}{ }^{-}\right.$, $\mathrm{CO}_{3}{ }^{=}$and $\left.\mathrm{OH}^{-}\right)$were estimated.

\begin{tabular}{|c|c|c|c|c|c|c|c|}
\hline $\mathbf{p H}$ & $\begin{array}{l}\mathrm{C} \\
\% \\
\end{array}$ & $\begin{array}{l}\mathbf{H} \\
\%\end{array}$ & $\begin{array}{l}\mathbf{N} \\
\%\end{array}$ & $\begin{array}{l}\mathrm{S} \\
\% \\
\end{array}$ & $\begin{array}{c}\text { Total } \mathrm{CaCO}_{3} \\
\% \\
\end{array}$ & $\begin{array}{c}\text { Surface area } \\
\mathrm{m}^{2} \mathrm{~g}^{-1} \\
\end{array}$ & $\begin{array}{c}\text { Total pore volume } \\
\mathrm{mm}^{3} \mathrm{~g}^{-1} \\
\end{array}$ \\
\hline 10.20 & 6.35 & 0.19 & Nil & 0.84 & 47.60 & 20.98 & 37.30 \\
\hline
\end{tabular}

Table 1. Some Characteristics of CKD 


\section{RESULTS AND DISCUSSION}

\section{Characteristics of CKD}

\section{Surface area and pore analysis}

The BET technique was used to determine the specific surface area of CKD samples. The adsorbed $\mathrm{N}_{2}$ per gram of sample was plotted versus the relative vapor pressure $(\mathrm{P} / \mathrm{Po})$ of $\mathrm{N}_{2}$ and exhibiting a smoothed lap rising up at high relative pressures with changing degrees of slope (Fig. 1). The data were evaluated by the Brunauer-Emmett-Teller (BET) equation to calculate surface area. The apparent specific surface area of CKD was $20.98 \mathrm{~m}^{2} / \mathrm{g}$ and total pore volume for CKD was $37.30 \mathrm{~mm}^{3} / \mathrm{g}$ (Table 1). Desorption BJH pore size distribution for CKD was identified in Table 2. The pore diameter of $<6 \mathrm{~nm}$ is the highest percent range between all pore diameter ranges. Therefore, the $\mathrm{BJH}$ pore diameters and pore volumes in CKD tends to relate to micropores. Micropores contribute to principally surface area, while macropores contribute as a channel to micropore surfaces (Yahya et al., 2015).

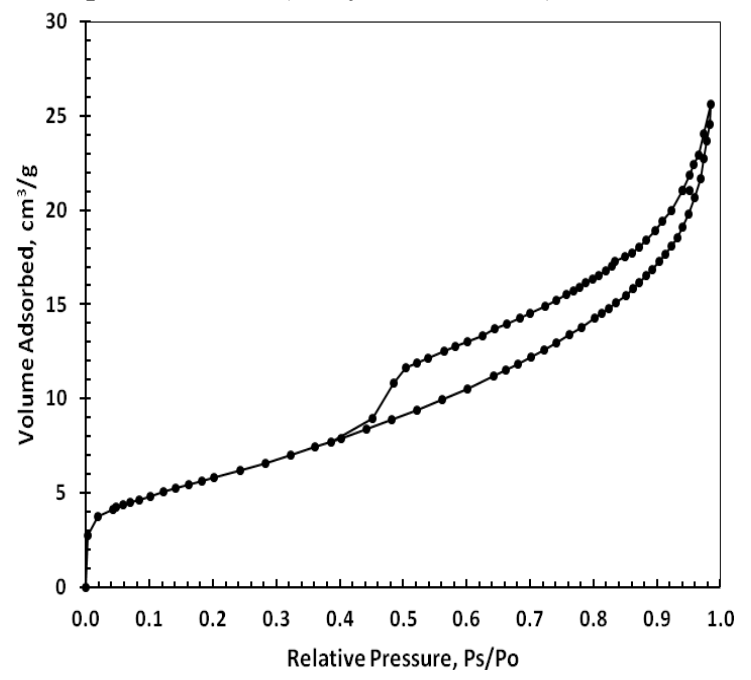

Fig 1. $\mathbf{N}_{2}$-adsorption isotherms of CKD

\section{FTIR analysis}

FTIR techniques were conducted to identify the functional groups of CKD before and after the sorption of $\mathrm{Cu}$ ions from aqueous solutions (Figure 2). The FTIR spectrum of CKD shows peak positions at 3,433.06, $1,454.23$, and $1,095.49 \mathrm{~cm}^{-1}$. The band at $3,433.06$ is appropriate to $\mathrm{O}-\mathrm{H}$ (hydroxyl) while the bands at 1,454.23 and 1,095.49 reflect the carbonate and silicate; similar data were obtained by (Al-Ghouti et al., 2003; Saraya and Aboul-Fetouh 2012; El-Refaey, 2016). Most studies utilize FTIR just to verify the availability of certain surface functional groups as part of sorbents structure, although probing the influence of these groups in relation to the metal binding process is also possible (Ochie et al. 2008). The comparison of CKD before and after the sorption of $\mathrm{Cu}$ ions showed slight shifts in FTIR bands with reducing transmission percentage at carbonate band (from 5.253 to $1.745 \%$ ) after sorption reaction (Figure 2). This confirms the attachment of copper ions on CKD surfaces.

Table 2. Desorption Barrett-Joyner-Halenda (BJH) pore size distribution of CKD

\begin{tabular}{lcc} 
Pore diameter range & \multicolumn{2}{c}{ Pore volume } \\
\cline { 2 - 3 } $\mathbf{n m}$ & $\mathbf{m l} / \mathbf{g}$ & $\mathbf{\%}$ \\
\hline$>80$ & 0.00283 & 7.88 \\
$20-80$ & 0.00955 & 26.55 \\
$16-20$ & 0.00217 & 6.02 \\
$12-16$ & 0.00182 & 5.07 \\
$10-12$ & 0.00170 & 4.74 \\
$8-10$ & 0.00158 & 4.40 \\
$6-8$ & 0.00276 & 7.68 \\
$<6$ & 0.01355 & 37.67 \\
\hline
\end{tabular}

Scanning electron microscopy (SEM)

The surface structure of CKD was analyzed by SEM before and after $\mathrm{Cu}^{+2}$ sorption experiments. The textural and morphological structure examination of CKD can be observed from the SEM photographs at $\times 5,000$ and $\mathrm{x}$ 10, 000 magnification (Figure 3). It was observed that CKD have the finest particle sizes and the sharp changes that were observed in porous structure of CKD. The CKD particles were covered by precipitates or complexes formation after sorption experiments. This may indicate various mechanisms for $\mathrm{Cu}^{+2}$ removals.

\section{Copper removal}

CKD showed a strong affinity to remove most $\mathrm{Cu}^{+2}$ after 10 min of the reaction, where $>90 \%$ of the removal at first $10 \mathrm{~min}$ increased to more than $99 \%$ after $1 \mathrm{~h}$ (Fig. 4). The effect of temperature on $\mathrm{Cu}^{+2}$ removal by $\mathrm{CKD}$ was not significant. The effect of temperature on $\mathrm{Cu}^{+2}$ removal reactions was not observed with $\mathrm{CKD}$. El-Refaey (2016) found the same trend of $\mathrm{Cd}^{+2}$ removals by CKD. Removal of Copper by CKD was time and temperature independence that might reflect the retention mechanisms. The $\mathrm{pH}$ has significant role in heavy metals removal. As presumed, the proceeding of $\mathrm{Cu}^{+2}$ removals by $\mathrm{CKD}$ favored with $\mathrm{pH}$ increases. The $\mathrm{pH}$ increased gradually from $6.70,6.40$ and 6.40 to 8.2 , 8.39 and 8.4 at $20{ }^{\circ} \mathrm{C}, 25{ }^{\circ} \mathrm{C}$ and $30{ }^{\circ} \mathrm{C}$, respectively after $96 \mathrm{~h}$. According to proposed mechanisms of metal ion binding to active surface of materials, $\mathrm{Cu}^{+2}$ removal could be achieved by electrostatic interaction with negatively charged surface functional groups (cation exchange), specific metal-ligand complexation involving surface functional groups of sorbents and/or physical sorption controlled by surface area and porosity 
(Brown, el al., 2000; Uchimiya et al., 2010; Saleh et al. 2016). Evidence from the present results confirmed that intervention of more than one mechanism can be proposed to control the removal process of $\mathrm{Cu}^{+2}$ depending on the sorbent characteristics, supported by the sharp changes in SEM images before and after sorption experiments of CKD (fig 3). The high efficacy of $\mathrm{Cu}^{+2}$ removal process by $\mathrm{CKD}$ could be explained by increasing $\mathrm{pH}$ solutions, calcium carbonate and calcium oxide contents, surface area, oxide content, and reducing metal solubility owed to enhanced sorption and/or precipitation (Zaki et al., 2007; Hal et al., 2012; Mackie and Walsh, 2012; El Zayat et al., 2014).

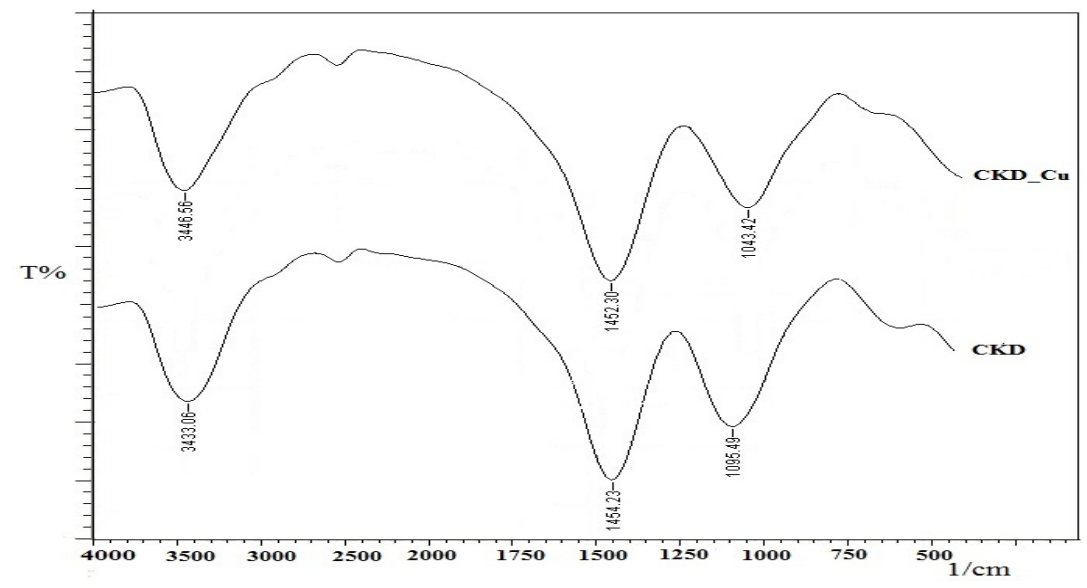

Fig 2. FTIR spectra of the CKD before and after the sorption of $\mathrm{Cu}$ ions experiments
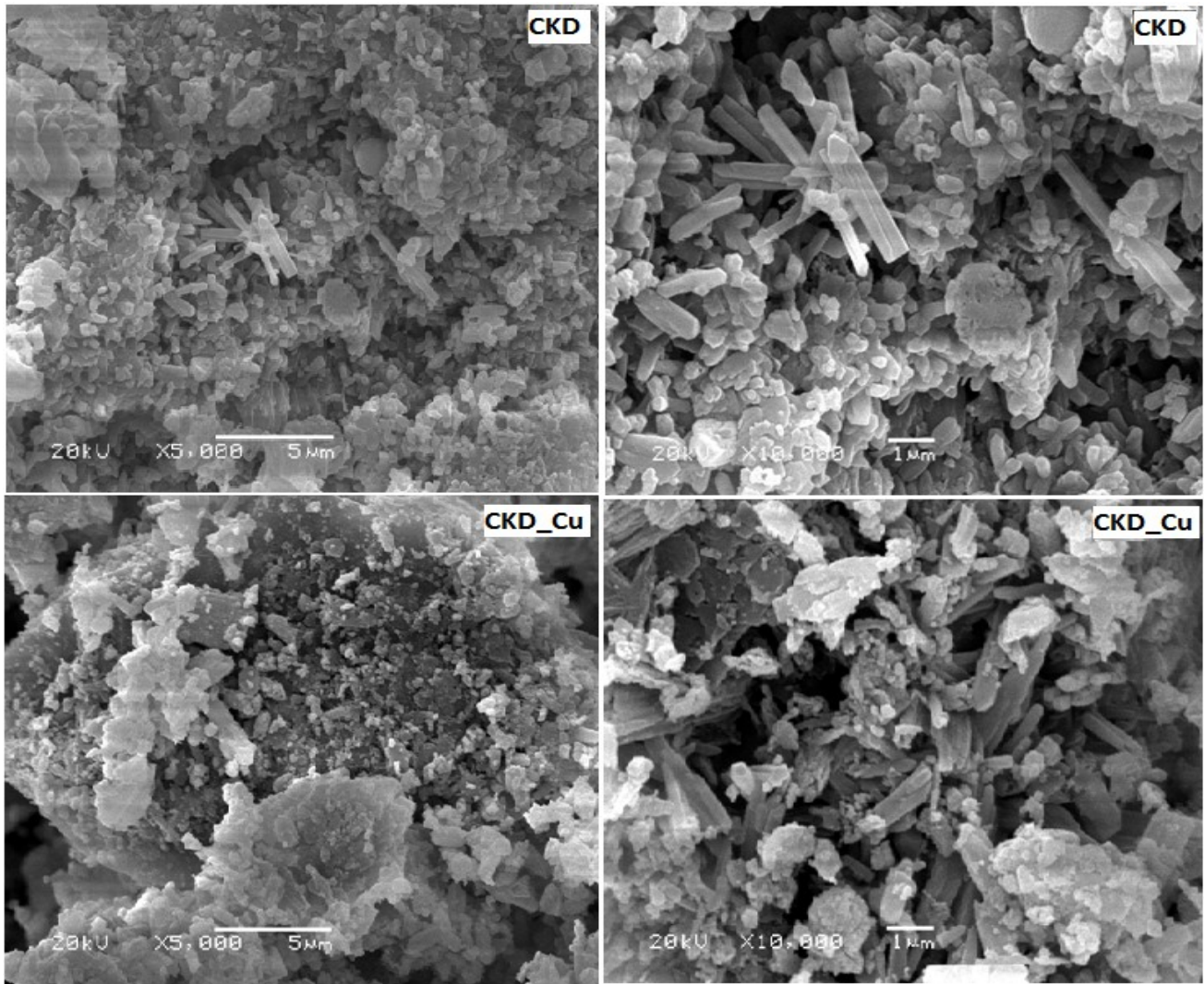

Fig 3. Scanning electron micrographs (SEM) of CKD before and after the removal reactions of $\mathrm{Cu}$ ions from aqueous solutions at $25^{\circ} \mathrm{C}$ 

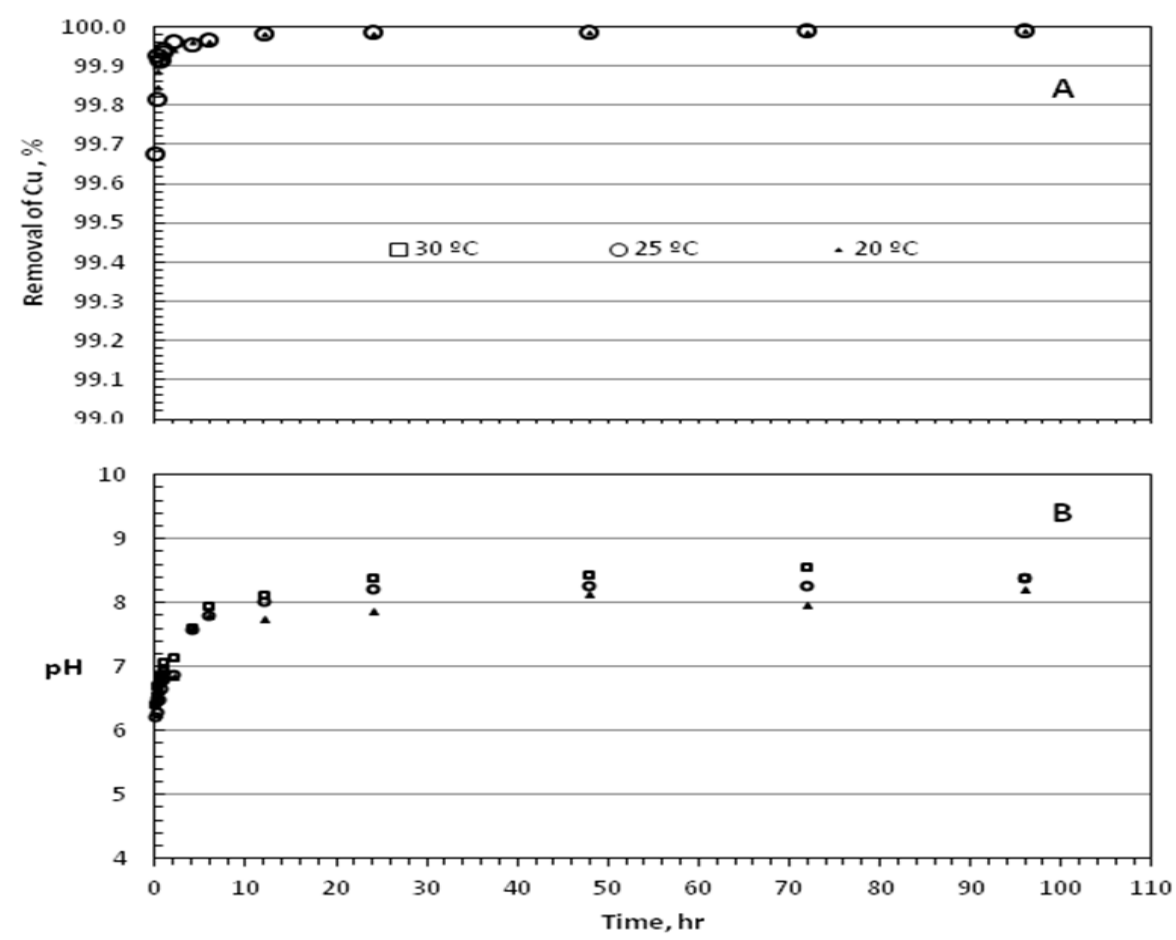

Fig 4. Removal of copper ions (A) and $\mathrm{pH}$ of aqueous solution (B) by CKD as a function of time and temperature

\section{Kinetic studies}

The fractional power, elovich, pseudo-first-order and pseudo-second-order kinetics models were applied. The fractional power model is an amended of the Freundlich equation and can be expressed by Equation (5) (Ho and McKay, 2002) or its linear form as given in equation (6):

$$
\begin{aligned}
& q_{t}=a t^{b} \\
& \ln q_{t}=\ln a+b \ln t
\end{aligned}
$$

where $\mathrm{q}_{\mathrm{t}}$ is the amount of $\mathrm{Cu}^{+2}$ sorbed by $\mathrm{CKD}$ at a time $t$, while $a$ and $b$ are constants with $b<1$; $a b$ is the specific sorption rate at unit time.

Elovich equation is useful model that can describe in a semi-empirical equation (Inyang et al., 2016), which is given by equations ( 7 and 8 ):

$$
\frac{d q_{t}}{d t}=\alpha \exp \left(-\beta q_{s}\right)
$$

or in integrated form:

$q_{t}=\frac{1}{\beta} \ln \alpha \beta+\frac{1}{\beta} \ln t$

where $\alpha$ is the initial rate of adsorption ( $\mathrm{mg} / \mathrm{g}$. $\mathrm{min}$ ), and $\beta$ is related to the surface coverage extent and activation energy for chemisorption $(\mathrm{g} / \mathrm{mg})$. Thus, the slope and intercept of the linear plot of $\mathrm{q}_{\mathrm{t}}$ versus $\ln \mathrm{t}$ give the constants.

The pseudo-first-order model (Lagergren, 1898) was applied and is given by:

$$
\log \left(q_{e}-q_{2}\right)=\log q_{9}-k_{1} t / 2.203
$$

where $\mathrm{k}_{1}$ is the pseudo-first-order rate constant $\left(\min ^{-1}\right)$ and qe $\left(\mathrm{mg} \mathrm{g}^{-1}\right)$ is the adsorption capacity at equilibrium and $\mathrm{q}_{\mathrm{t}}\left(\mathrm{mg} \mathrm{g}^{-1}\right)$ is the amount of metal adsorbed at any time $(\mathrm{t})$. Also, pseudo-second-order model (Ho, 2006) was applied and is expressed as:

$$
\frac{t}{a_{t}}=\frac{1}{k_{2} a_{\theta}^{2}}+\frac{t}{a_{e}}
$$

where $\mathrm{k}_{2}(\mathrm{~g} \mathrm{mg} / \mathrm{min})$ is the pseudo-second-order rate constant. The values of $\mathrm{q}_{\mathrm{e}}, \mathrm{k}_{1}$ and $\mathrm{k}_{2}$ were obtained from the slopes and intercepts of the adsorption Fractional power, kinetic models have been applied to estimate the rate-controlling mechanism of the adsorption process. The parameters are recorded in Table 3, where $a$ and $b$ are constants related to specific sorption rate, $\alpha$ is the rate of initial adsorption $(\mathrm{mg} / \mathrm{g}$. min), $\beta$ is the desorption constant ( $\mathrm{g} \mathrm{mg} / \mathrm{min}$ ), qe can be regarded as the amounts of metals adsorbed on the adsorbent $(\mathrm{mg} / \mathrm{g})$ at equilibrium, $\mathrm{k}_{1}$ and $\mathrm{k}_{2}$ and $\min ^{-1}$ is the rate constant, respectively. 
Table 3. Kinetic parameters of $\mathrm{Cu}^{+2}$ on CKD at various temperatures

\begin{tabular}{lccc}
\hline Model & $\mathbf{2 0}^{\mathbf{0}} \mathbf{C}$ & $\mathbf{2 5}^{\mathbf{0}} \mathbf{C}$ & $\mathbf{3 0}^{\mathbf{0}} \mathbf{C}$ \\
\hline Fractional power & & & \\
$\mathrm{A}$ & 3809.54 & 3808.02 & 3809.54 \\
$\mathrm{~B}$ & $1.60 \times 10^{-4}$ & $2.90 \times 10^{-4}$ & $1.80 \times 10^{-4}$ \\
$\mathrm{r}^{2}$ & 0.91 & 0.59 & 0.85 \\
\hline Elovich & & & \\
$\mathrm{A}$ & $2.38 \times 10^{71}$ & $3.00 \times 10^{58}$ & $7.63 \times 10^{67}$ \\
$\mathrm{~B}$ & 1.69 & 0.91 & 1.48 \\
$\mathrm{r}^{2}$ & 0.91 & 0.60 & 0.85 \\
\hline Pseudo-first-order & & & \\
$\mathrm{q}_{\mathrm{e}}$ & 15244.35 & 15244.35 & 15244.35 \\
$\mathrm{~K}_{1}$ & $2.00 \times 10^{-6}$ & $3.00 \times 10^{-6}$ & $2.30 \times 10^{-6}$ \\
$\mathrm{r}^{2}$ & 0.43 & 0.19 & 0.42 \\
\hline Pseudo-second-order & & & \\
$\mathrm{q}_{\mathrm{e}}$ & 3812.43 & 3812.43 & 3812.43 \\
$\mathrm{~K}_{2}$ & 0.34 & 0.38 & 0.34 \\
$\mathrm{r}^{2}$ & 0.99 & 0.99 & 0.99 \\
\hline
\end{tabular}

From the kinetic parameters which have been calculated at different temperatures and times listed in Table 3, the high values of the coefficient of determination $\left(r^{2}>0.99\right)$ confirmed that the pseudo-second-order model was most adequate to represent the adsorption kinetics of Copper onto CKD.

Moreover, experimental qe values are very close to those predicted from the pseudo-second- order kinetic model $\left(\mathrm{r}^{2}>0.99\right)$. Therefore, the obtained results indicated that the adsorption of $\mathrm{Cu}^{+2}$ could be best described by the pseudo-second-order model (Fig. 5).

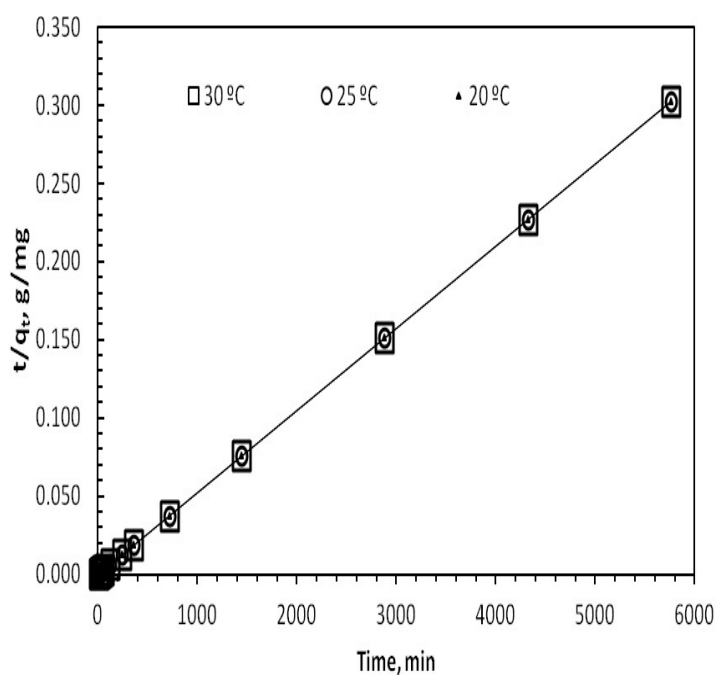

Fig 5. Pseudo-second-order plots for $\mathrm{Cu}^{+2}$ removal kinetics by CKD at different temperatures

\section{Thermodynamic studies}

Thermodynamic considerations of the sorption process are essential to identify whether the process is spontaneous or not and understanding the removal mechanisms. Thermodynamic parameters such as Gibbs free energy change $\left(\Delta \mathrm{G}^{\circ}\right)$, enthalpy change $\left(\Delta \mathrm{H}^{\circ}\right)$ and the entropy change $\left(\Delta \mathrm{S}^{\circ}\right)$ can be estimated using equilibrium constants changing with temperature. Spontaneity of a chemical reaction can be indicated by the changes in the Gibbs free energy and therefore is an important criterion for spontaneity (Ucun et.al, 2008). The thermodynamic parameters $\left(\Delta \mathrm{H}^{\mathrm{o}}, \Delta \mathrm{G}^{\mathrm{o}}\right.$ and $\left.\Delta \mathrm{S}^{\mathrm{o}}\right)$ were calculated from the sorption data. The Gibbs free energy change of the reaction was calculated from equation (11) (K111 $\square$ etal., 2013):

$\Delta \mathrm{G}^{\circ}=-\mathrm{RT} \ln \mathrm{K}_{\mathrm{L}}$

where $\mathrm{R}$ is gas constant $(8.314 \mathrm{~J} / \mathrm{mol} \mathrm{K}), \mathrm{K}_{\mathrm{L}}$ is equilibrium constant and $\mathrm{T}$ is absolute temperature $(\mathrm{K})$. The $\mathrm{K}_{\mathrm{L}}$ value was determined using equation (12):

$\mathrm{K}_{\mathrm{L}}=\frac{q_{e}}{C_{e}}$

where $\mathrm{q}_{\mathrm{e}}$ and $\mathrm{C}_{\mathrm{e}}$ is the equilibrium concentration of metal ions on adsorbent $(\mathrm{mg} / \mathrm{g})$ and in the solution $(\mathrm{mg} / \mathrm{L})$, respectively. Relations between $\Delta \mathrm{G}^{\circ}, \Delta \mathrm{H}^{\circ}$ and $\Delta \mathrm{S}^{\circ}$ can be expressed by the following equations:

$\Delta \mathrm{G}^{\circ}=\Delta \mathrm{H}^{\circ}-\mathrm{T} \Delta \mathrm{S}^{\circ}$

Eq (11) can be rewritten as

$\ln \mathrm{K}_{\mathrm{L}}=-\frac{\Delta \mathrm{G}^{\circ}}{R T}=-\frac{\Delta \mathrm{H}^{\circ}}{R T}+\frac{\Delta \mathrm{S}^{\circ}}{R}$

According to Eq. (14), $\Delta \mathrm{H}^{\circ}$ and $\Delta \mathrm{S}^{\circ}$ parameters can be obtained from the slope and intercept of the plot of $\ln$ $\mathrm{K}_{\mathrm{L}}$ versus $1 / \mathrm{T}$, respectively (Meena et al., 2008; Sari et 
al., 2007; Ucun etal., 2008, Kilic et al., 2013). The calculated values of Gibbs free energy change $\left(\Delta G^{\circ}\right)$, enthalpy $\left(\Delta \mathrm{H}^{\circ}\right)$, and entropy $\left(\Delta \mathrm{S}^{\circ}\right)$ are given in Table (4). The negative values of $\Delta \mathrm{G}^{\circ}$ indicate that the process is thermodynamically feasible and spontaneous. The negative value of $\Delta \mathrm{H}^{\circ}$ pointed out that the nature of adsorption process is exothermic. The positive value of $\Delta \mathrm{S}^{\circ}$ reflects the affinity of CKD for $\mathrm{Cu}^{++}$and suggests increasing in randomness at the solid/solution interface during the removal process.

Table 4. Thermodynamic parameters of the removal of $\mathrm{Cu}^{2+}$ by CKD from aqueous solutions

\begin{tabular}{lccc}
\hline $\mathbf{T}^{\mathbf{0}} \mathbf{C}$ & $\begin{array}{c}\Delta \mathbf{G}^{\mathbf{0}} \\
\mathrm{kJ} / \mathrm{mol}\end{array}$ & $\begin{array}{c}\Delta \mathbf{S}^{\mathbf{0}} \\
\mathrm{J} / \mathrm{mol} \mathrm{K}\end{array}$ & $\begin{array}{c}\Delta \mathbf{H}^{\mathbf{0}} \\
\mathrm{kJ} / \mathrm{mol}\end{array}$ \\
\hline 20 & -18.17 & & \\
25 & -18.58 & 2.14 & -0.37 \\
30 & -19.66 & & \\
\hline
\end{tabular}

\section{Copper solubility behavior}

The sorption isotherm results for $\mathrm{CKD}\left(47 \% \mathrm{CaCO}_{3}\right)$ showed a higher affinity of surfaces to $\mathrm{Cu}$ ions. The $\mathrm{pH}$ and carbonate contents are known to play a major role in influencing the solubility as well as sorption processes in experiments condition. A decrease in soluble $\mathrm{Cu}^{++}$ was accompanied with the increase of $\mathrm{pH}$ values (Fig. 6). Ion activity of copper was computed during $\mathrm{Cu}$ reaction with $\mathrm{CKD}$ for interval time of $10 \mathrm{~min}, 1,2,6$ and $24 \mathrm{~h}$. In an attempt to figure out the probability of $\mathrm{Cu}$ compounds formation under the experiment conditions, copper activities was calculated for drawing the solubility isotherms lines of $\mathrm{Cu} \mathrm{CO}_{3}, \mathrm{Cu}(\mathrm{OH})_{2}$, $\mathrm{Cu}_{2}(\mathrm{OH})_{2} \mathrm{CO}_{3}, \mathrm{CuSO}_{4} \cdot 5 \mathrm{H}_{2} \mathrm{O}, \mathrm{Cu}_{4}(\mathrm{OH})_{6} \mathrm{SO}_{4}$ and $\mathrm{Ca} \mathrm{CO}_{3}$ at atmospheric partial pressure of carbon dioxide $\left(\mathrm{PCO}_{2}\right.$ $\left.=10^{-3.52} \mathrm{~atm}\right)$ on the solubility diagram of $\log \mathrm{Me}^{2+}-$ $\mathrm{pH}$ using solubility constants given by Lindsay (1979). The computed ion activities of $\mathrm{Cu}^{2+}$ and $\mathrm{Ca}^{2+}$ for $\mathrm{CKD}$ suspensions were plotted on $\log \mathrm{Me}^{2+}-\mathrm{pH}$ diagram (Fig. 6). The computed copper activities for $\mathrm{Cu} \mathrm{CO}_{3}$ were found to be lower than the solubility products of their minerals during the reaction time. (Fig. 6-A). Opposing to that, the computed copper activities were higher than calculated solubility that based on the actual experimental partial pressure of $\mathrm{CO}_{2}$ (Fig. 6-B). The apparent discrepancy is due to the differences in $\mathrm{P} \mathrm{CO}_{2}$ as a basis for the calculation, as $\mathrm{P} \mathrm{CO}_{2}$ was not constant during the experimental time. The partial pressure of $\mathrm{CO}_{2}$ in $\mathrm{Cu}-\mathrm{CKD}\left(47 \% \quad \mathrm{Ca} \quad \mathrm{CO}_{3}\right)$ suspensions was estimated using $\mathrm{pH}$ value and solution $\mathrm{HCO}_{3}{ }^{-}$activity and it was ranged from 0.021 to $0.0018 \mathrm{~atm}$. The calculated copper activities values for CKD (47\%) showed porobability of $\mathrm{Cu}^{2+}$ precipitation after six hours (Fig. 6-B). On other hand, results pointed out that $\mathrm{Cu}$ precipitation had no effect on $\mathrm{Ca} \mathrm{CO}_{3}$ solubility of CKD (Fig. 6-Aand B).
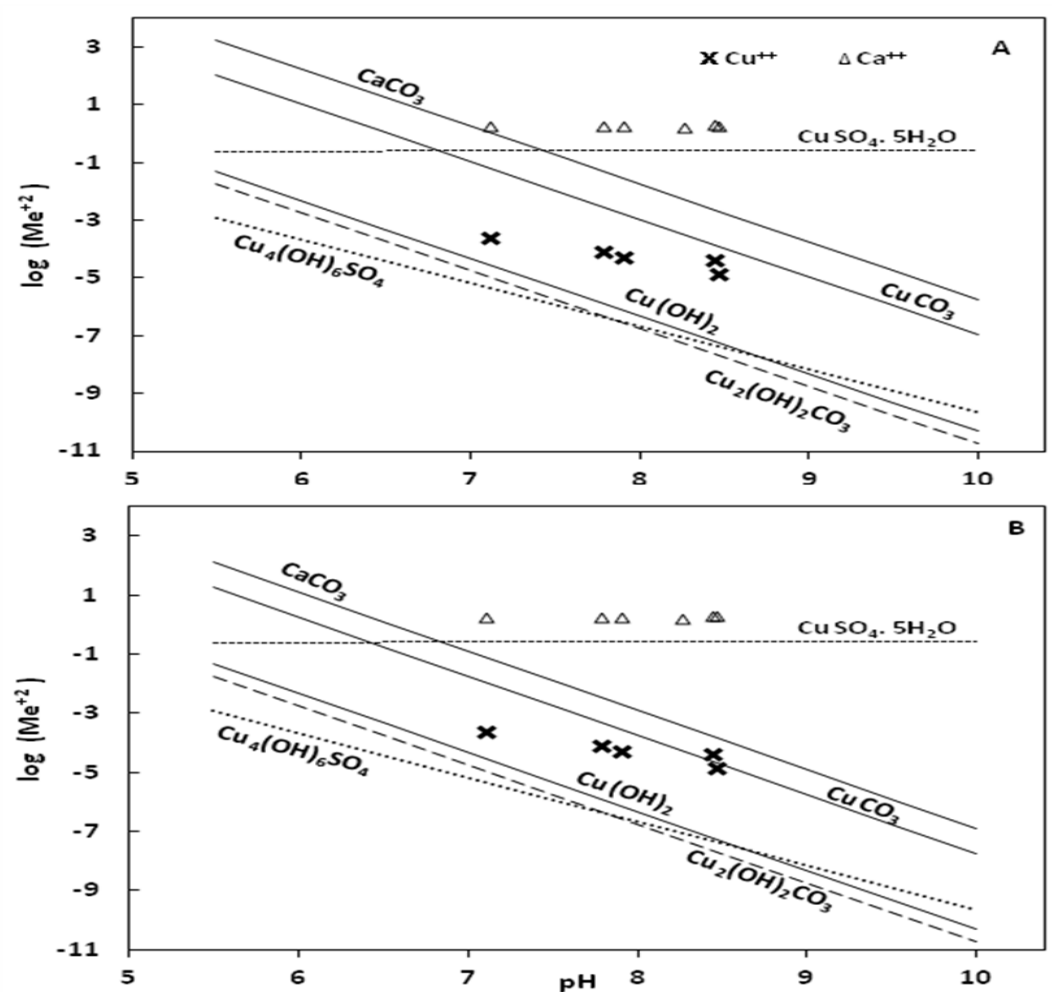

Fig. 6. Calculated ion activities of $\mathrm{Cu}^{2+}$ and $\mathrm{Ca}^{2+}$ for $\mathrm{CKD}$ suspensions (A) $\mathrm{Log} \mathrm{PCO}_{2}=-3.52$ atm and (B) $\mathrm{Log}$ $\mathrm{PCO}_{2}=-2.36 \mathrm{~atm}$ (actual experimental condition) 
The calculated $\mathrm{CaCO}_{3}$ solubility product indicates very high supper saturation; $\mathrm{Ca} \mathrm{CO}_{3}$ may be highly dissolved due to high chloride concentration as back ground solution. Conducting solubility experiments with controlled $\mathrm{PCO}_{2}$ is needed to differentiate between possibilities of forming $\mathrm{CuCO}_{3}, \mathrm{Cu}(\mathrm{OH})_{2}$ or $\mathrm{Cu}_{2}(\mathrm{OH})_{2} \mathrm{CO}_{3}, \quad \mathrm{CuSO}_{4} \cdot 5 \mathrm{H}_{2} \mathrm{O}$ and $\mathrm{Cu}_{4}(\mathrm{OH})_{6} \mathrm{SO}_{4}$ compounds and find out their effect on $\mathrm{Ca} \mathrm{CO}_{3} \mathrm{CaSO}_{4}$ solubility (Lindsay 1979; Sposito, 1989).

Ion activity product, IAP can also be used as a guide in determining the achievement of dissolution equilibrium. This can be obtained by examining measured value of relative saturation $(\Omega)$ for different solid phase (Sposito, 1989):

$\Omega=\mathrm{IAP} / \mathrm{K}_{\mathrm{so}}$

Where $\mathrm{K}_{\mathrm{so}}$ is the solubility product constant and IAP is the ion activity product. If $\Omega$ is less than 1 , the solution will be under saturated. Otherwise, if $\Omega$ is more than 1 , the solution will be supper saturated and when the solution reaction is at equilibrium $\Omega$ is equals 1 . Figure (7) shows the approach of $\Omega$ with respect to $\mathrm{Cu}$ $\mathrm{CO}_{3}, \mathrm{Cu}(\mathrm{OH})_{2}$ and $\mathrm{Cu}_{2}(\mathrm{OH})_{2} \mathrm{CO}_{3}$ compounds during reaction time. For $\mathrm{Cu}(\mathrm{OH})_{2}$ and $\mathrm{Cu}_{2}(\mathrm{OH})_{2} \mathrm{CO}_{3}, \Omega$ is supper saturated all over the study time. On other hand $\Omega$ for $\mathrm{Cu} \mathrm{CO}_{3}$ tends to move from under saturation during the first two hours of reaction to reach equilibrium and be supper saturation after 6 hours. Therefore, the solubility of $\mathrm{Cu}^{++}$in $\mathrm{Cu}-\mathrm{CKD}$ system under experiment condition may be controlled by $\mathrm{Cu}$ $\mathrm{CO}_{3}$ precipitation. This assumption is confirmed not only by shifting of FTIR band but also by reducing transitions percentage (5.253 to 1.745) of FTIR carbonate band $\left(1454.23 \mathrm{~cm}^{-1}\right)$ after copper reaction with CKD.

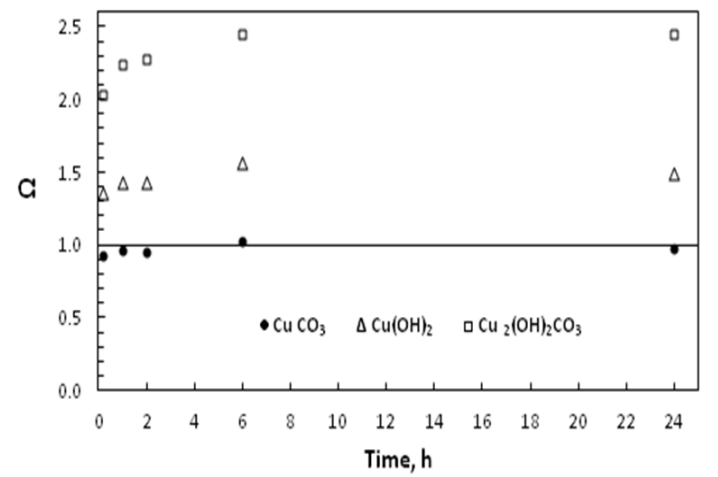

Fig. 7. Estimated value of relative saturation $(\Omega)$ for $\mathrm{Cu} \mathrm{CO} 3, \mathrm{Cu}(\mathrm{OH})_{2}$ and $\mathrm{Cu}_{2}(\mathrm{OH})_{2} \mathrm{CO}_{3}$ compounds in $\mathrm{Cu}-\mathrm{CKD}$ suspensions during reaction time

\section{CONCLUSION}

The results pointed out that the potential of CKD for removing $\mathrm{Cu}^{2+}$ from aqueous solutions within the first 10 min of the batch reaction preceded with no effect by temperature or time. The high efficacy of CKD explained by increasing $\mathrm{pH}$ solutions, high content of calcium carbonate, surface area, oxide content, and reducing metal solubility owed to enhanced sorption and/or precipitation. The pseudo-second-order kinetic model agrees very well with the dynamic behavior for the removal of $\mathrm{Cu}^{2+}$. The negative values of $\Delta \mathrm{G}^{\circ}$ indicated spontaneity and feasibility of the adsorption process. The negative value of $\Delta \mathrm{H}^{\circ}$ shows that the nature of adsorption process is exothermic. The positive value of $\Delta \mathrm{S}^{\circ}$ explains the affinity of $\mathrm{Cu}^{++}$for $\mathrm{CKD}$ during the removal process. The solubility study of $\mathrm{Cu}-\mathrm{CKD}$ system suggested that $\mathrm{Cu} \mathrm{CO}_{3}$ precipitation could control copper solubility under experimental condition. That was confirmed by shifting and reducing transmission percentage of FTIR carbonate band.

\section{ACKNOWLEDGE}

The author thanks Prof. Maher Saleh for his support, helpful cooperation, and offering lab facilities.

\section{REFERENCES}

Ahmad, R., R. Kumar and S. Haseeb. 2010. Adsorption of $\mathrm{Cu}^{2+}$ from aqueous solution onto iron oxide coated eggshell powder: Evaluation of equilibrium, isotherms, kinetics, and regeneration capacity. Arabian Journal of Chemistry 5: 353-359.

Al-Ghouti, M. A., M. A. M. Khraisheh, S. J. Allen and M. N. Ahmad. 2003. The removal of dyes from textile wastewater: a study of the physical characteristics and adsorption mechanisms of diatomaceous earth. Journal of Environmental Management 69: 229-238.

Barakat, M.A. 2011. New trends in removing heavy metals from industrial wastewater. Arabian Journal of Chemistry 4:361-377.

Bayat, B. 2002. Comparative study of adsorption properties of Turkish fly ashes. II. The case of chromium (VI) and cadmium (II). Journal of Hazardous Materials, B95 : 275 290.

Bilal M., J.A. Shah, T. Ashfaq, S.M.H. Gardazi, A.A. Tahir, A. Pervez, H. Haroon and Q. Mahmood 2013. Waste biomass adsorbents for copper removal from industrial wastewater - A review. Journal of Hazardous Materials 263: 322-333.

Brown, P.A., S.A. Gill and S.J. Allen. 2000. Metal removal from wastewater using peat. Water Res. 16: 3907-3916.

Chen, X. C., Y. P. Wang, Q. Lin, J. Y. Shi, W. X. Wu and Y. X. Chen. 2005. Biosorption of copper(II) and zinc(II) from aqueous solution by Pseudomonas putida CZ1. Colloids and Surfaces B: Biointerfaces 46: 101-107. 
El Zayat, M., S. Elagroudy and S. El Haggar. 2014. Equilibrium analysis for heavy metal cation removal using cement kiln dust. Water Science \& Technology 70: 10111018.

El-Refaey, Ahmed A. 2016. Comparative performance of cement kiln dust andactivated carbon in removal of cadmium from aqueous solutions. Water Science \& Technology 73: 1691- 1699.

Fenglian Fu and Q Wang. 2011. Removal of heavy metal ions from wastewaters: A review. Journal of Environmental Management 92: 407-418.

Griffin, R. A. and J.J. Jurinak. 1973. Estimation of activity coefficients from the electrical conductivity of natural aquatic systems and soils extracts. Soil Sci. 116:26-30.

Hal, B., L.Evans and R. Lamber. 2012. Effects of cement or lime on $\mathrm{Cd}, \mathrm{Co}, \mathrm{Cu}, \mathrm{Ni}, \mathrm{Pb}, \mathrm{Sb}$ and $\mathrm{Zn}$ mobility in fieldcontaminated and aged soils. Journal of Hazardous Materials 199-200: 119-127.

Ho, Y. S. 2006. Second-order kinetic model for the sorption of cadmium onto tree fern: a comparison of linear and nonlinear methods. Water Research 40: 119-125.

Ho, Y. S. and G. McKay. 2002. Application of kinetic models to the sorption of copper (II) on to peat. Adsorption Science \&Technology 20: 797-815.

Huang, C.P., and A.L. Morehart. 1990. The removal of Cu (II) from dilute aqueous solutions by Saccharomyces cerevisae. Water Research 24: 433-439.

Ibrahim, H.G., A.Y. Okasha and M. S. ElAtrash. 2009. Using cement kiln dust to treat tannery wastewater effluents. $11^{\text {th }}$ international conference on Environmental science and Technology Crete, Greece.

Inyang,H. I., A. Onwawoma, and S. Bae. 2016. The Elovich equation as a predictor of lead and cadmium sorption rates on contaminant barrier minerals. Soil and Tillage Research 155:124-132.

Karabulut S., A. Karabakan, A. Denizli, Y. Yurum. 2000. Batch removal of copper(II) and zinc(II) from aqueous solutions with low-rank Turkish coals. Separation and Purification Technology 18: 177-184.

Kılıc, Murat, $\square$ isem Kırbıyık, Özge $\square$ epelioğullar and Ayşe E. Pütün. 2013. Adsorption of heavy metal ions from aqueous solutions by bio-char, aby-product of pyrolysis. Applied Surface Science 283:856-862.

Lagergren, S. 1898. About the theory of so-called adsorption of soluble substances. Kungliga Svenska Vetenskapsakademiens 24:1-39.

Lindsay, Willard L. 1979. Chemical Equilibria in Soils. John Willey\& Sons, New York.

Suzuki, M.. 1997. Role of adsorption in water environment processes. Water Science and Technology 35: pp. 1-11

Mackie, Allison L. and Margaret E. Walsh. 2012. Bench-scale study of active mine water treatment using cement kiln dust (CKD) as a neutralization agent. Water Research 46: 327-334.
Mahmoued, E. K. 2010. Cement kiln dust and coal filters treatment of textile industrial effluents. Desalination 255:175-178

Meena, A.K., K. Kadirvelu, G.K. Mishraa, C. Rajagopal and P.N. Nagar. 2008. Adsorption of $\mathrm{Pb}(\mathrm{II})$ and $\mathrm{Cd}(\mathrm{II})$ metal ions from aqueous solutions by mustard husk, J. Hazard Mater. 150: 619-625.

Nader, M. 2015. Surface area: Brunauer-Emmett-Teller (BET). In:Progress in Filtration and Separation (S. Tarleton, ed.).Academic Press, London, UK, pp. 585-608.

Ochie, V. A., K. Trilestari, J. Sunarso, N. Indraswati and S. Ismadji. 2008. Review recent progress on biosorption of heavy metals from liquids using low cost biosorbents: Characterization, biosorption parameters and mechanism studies. Clean 36: 937-962.

Park, M. and S. Komarneni. 1998. Rapid synthesis of AlPO411 and cloverite by microwave hydrothermal processing. Microporous and Mesoporous Materials 20: 39-44.

Paulino, A.T., F.A.S. Minasse, M.R. Guilherme, A.V. Reis, E.C. Muniz, J. Nozaki. 2006. Novel adsorbent based on silkworm chrysalides for removal of heavy metals from wastewaters. J. Colloid Interface Sci. 301: 479-487.

Pigaga, A., R. Juskenas, D. Virbalyte, M.G. Klimantaviciute and V. Pakstas. 2005. The use of cement kiln dust for the removal of heavy metal ions from aqueous solutions. Trans. Inst.Met. Finish. 83: 210-214.

Rahman, M. K., S. Rehman and O. S. B. Al-Amoudi. 2011. Literature review on cement kiln dust usage in soil and waste stabilization and experimental investigation IJRRAS 7: 77-87.

Salem, A. and E. Velayi. 2012. Application of hydroxyapatite and cement kiln dust mixture in adsorption of lead ions from aqueous solution. Journal of Industrial and Engineering Chemistry 18: 1216-1222.

Saleh, M. E., , A. A. El-Refaey and A. H. Mahmoud. 2015. Effectiveness of sunflower seed husk biochar for removing copper ions from wastewater: a comparative study. Soil \&Water Research 11: 53-63.

Saraya, M. E. I. and M. E. Aboul-Fetouh. 2012. Utilization from cement kiln dust in removal of acid dyes. American Journal of Environmental Sciences 8: 16-24.

Sari, A., M. Tuzen, Ö.D. Uluözlü and M. Soylak. 2007. Biosorption of $\mathrm{Pb}(\mathrm{II})$ and $\mathrm{Ni}(\mathrm{II})$ fromaqueous solution by lichen (Cladonia furcata) biomass, Biochem. Eng. J. 37:151-158.

Shareef, K. M. 2009. Sorbents for contaminant uptake from aqueous solution. Part I: heavy metals. World J Agric Sci 5:819-831.

Sobecka, E. 2001. Changes in the iron level in the organs and tissues of wels catfish, silurus glanis 1 . caused by nickel Acta Ichthyol. Piscat. 31: 127-143.

Sposito, Garrison. 1989. The chemistry of Soils. Oxford Unviversity press, Inc, New York. 
Suzuki, Yoshihiro, Takuji Kametani and Toshiroh Maruyama. 2005. Removal of heavy metals from aqueous solution by nonliving Ulva seaweed as biosorbent. Water Research 39: 1803-1808.

Uchimiya, M., I. M. Lima, K. T. Klasson, S. Chang, L. H. Wartelle and J. E. Rodgers2010. Immobilization of heavy metal ions (CuII, CdII, NiII, PbII) by broiler litter-derived biochars in water and soil. Journal of Agricultural and Food Chemistry 58: 5538-5544.

Ucun, H., Y.K. Bayhan and Y. Kaya. 2008. Kinetic and thermodynamic studies of the biosorption of $\mathrm{Cr}(\mathrm{VI})$ by Pinus sylvestris Linn, J. Hazard. Mater. 153: 52-59.
WHO. 2004. Copper in Drinking-water. World Health Organization, Geneva, Switzerland. http://www.who.int/water_sanitation_health/dwq/chemical s/copper.pdf (accessed 29 December 2016).

Yahya, A. M.,Z. Al-Qodah and C.W. Z.Ngah. 2015. Agricultural bio-waste materials as potential sustainable precursors used for activated carbon production: A review.Renewable and Sustainable Energy Reviews 46: 218-235.

Zaki, Nagwan G., I.A. Khattab and N.M. Abd El-Monem. 2007. Removal of some heavy metals by CKD leachate. Journal of Hazardous Materials 147: 21-27.

\section{الملخص العربي}

دراسة إزالة أيونات النحاس من المحاليل المائية بواسظة التراب الإسمنتى كناتج ثانوى من صناعة الاسمنت

$$
\text { أحمد عبد الخالق الرفاعى }
$$

وجد نطابق واضـح وبشكل جيد لنمــوذج الدرجــة الثانيــة Pseudo-second-order الديناميكا الحرارية للتنبؤ بطبيعة الامتصاص من تغير فــى

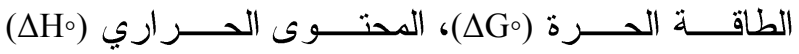

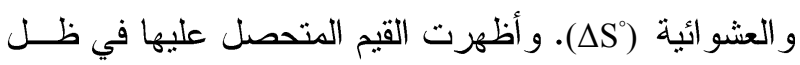
ظروف التجربة أن حدوث هذه العمليـــة كانـــت تلقائيــة، و التفاعل طارد للحر ارة و القابلية المرتفعة لاز الـــة ايونـــات

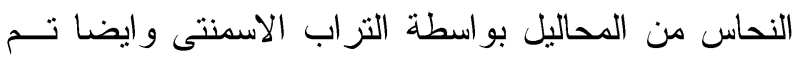

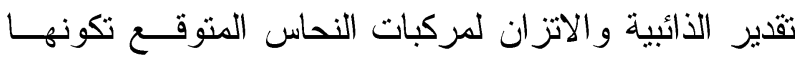

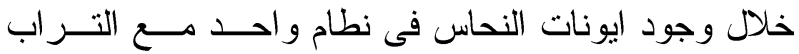
الاسمنتىي واقترح أن ترسيب مركب كربونات النحاس قد

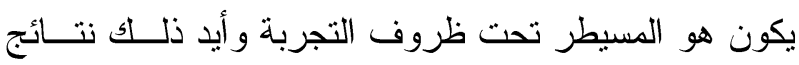
التحليل الطيفى. وبذلك أوضحت النتائج أن التراب الاسمنتى كناتج ثانوى من صناعةالاسمنت ومنخفض التكاليف يمكـن

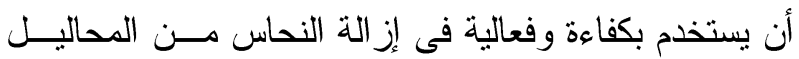

قامت الدر اسة بــالتحقق مــن أداء التــر اب الإســـنتى (CKD)، كناتج ثانوى من عملية تصنيع الاسمنت، فى از الة

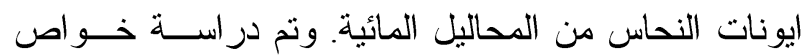

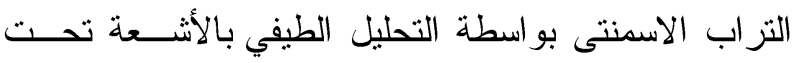

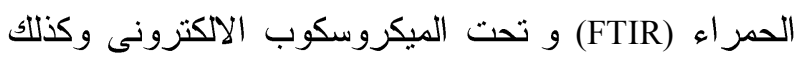

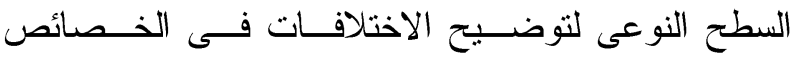

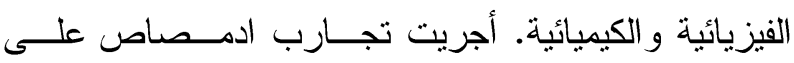

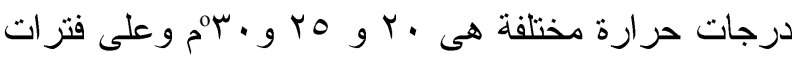
زمنية امتدت الى 97 ساعة لدر اسة كفاءة التزاب الاسمنتى

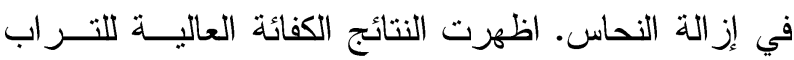

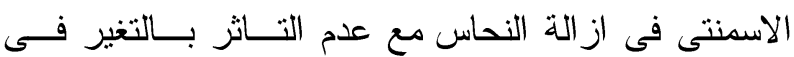

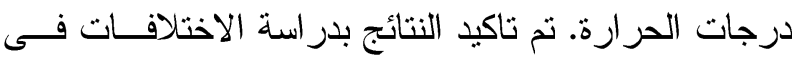

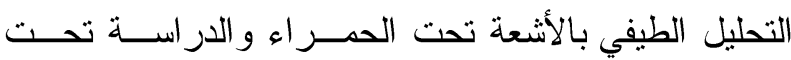

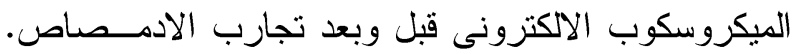

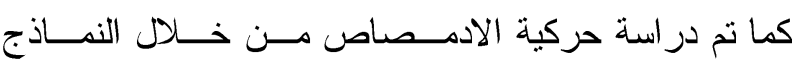

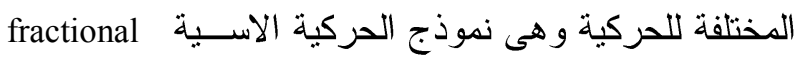
power ونموذج مونموذج الدرجة الاولى والثانية. 